\title{
Effect Of Young Age in Murder Felony (Comparative Study Between Islamic Jurisprudence and Indonesian Law)
}

\author{
Islamul Haq, M. Ali Rusdi Bedong, Abdul Syatar \\ STAIN Parepare \\ islamulhaq@stainparepare.ac.id
}

\begin{abstract}
This research was a comparative study on the effect of young age in the crime of murder between Islamic jurisprudence and Indonesian law. The presence of children around us needs attention, especially with regard to their behavior, which is out of control. the phenomenon of their deviation is one of the negative social phenomenon which required protection, guidance and education. According to previous studies, children who deviated and were not controlled would become a criminal when he reaches adulthood. Nowadays, the children's delinquency is widely spread, they are involved in committing crimes such as drugs, theft, fighting, and increased to murder. This research will focus on the murder committed by under age children, because murder is a very dangerous crime to the indivdual life and is one of the law violation againts the five principles of shariah (daruriyat al khamsah).
\end{abstract}

Keyword: Islamic jurisprudence, Indonesian law, daruriyat al khamsah 


\section{أثر صغر السن في جناية القتل \\ (دراسة مقارنة بين الفقه الإسلامي والقانون الإندونيسي) \\ Islamul Haq \\ M. Ali Rusdi Bedong \\ Abdul Syatar \\ (islamulhaq@stainparepare.ac.id)}

التجريل

هذا البحث دراسة مقارنة عن الأثر صغر السن في جناية القتل بين الفقه الإسالمي

والقانون الإندونيسي. وجود الأطفال حولنا حاليا فهي بحاجة للحصول إلى الإهتمام، خاصة فيما يتعلق بسلوكهم التي خارجة عن السيطرة لأن ظاهرة انحرافهم تعد من الظواهر الاجتماعية السلبية الشائكة تحتاج إلى حماية وتوجيه وتربية، فالصغير الذي الخرف ولم يقم بأعوجه سيتحول إلى بحرم عندما يصل إلى مرحلة البلوغ.وقد ازداد الآن انحراف الأطفال وتصرفات سيئة تصدر عنهم وسلوكات ضارة بهم وبمجتمعهم، كالمخدرات والسرقة وجرائم الجرح والضرب حتى جريمة القتل، وسيركز هذا البحث في مسألة جريمة القتل الذي ارتكب الأطفال، لأن موضوع القتل مهم جدا وخطير يمس حياة الفرد، وأحد كليات الخمس التي جاء بها الإسالام هي نفس البشرية. كلمة الرئسية: الفقه الإسلامي، القانون الإندونيسي، كليات الخمس 
مقدمة

أنزل الله تعالى الشريعة الإسلامية لتحقيق مصالح العباد وحفظ هذه المصالح ودفع

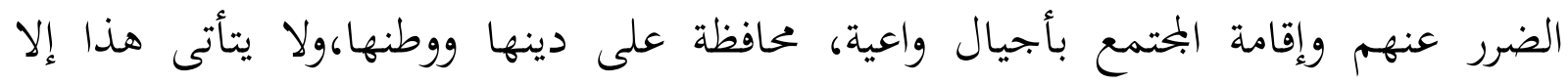

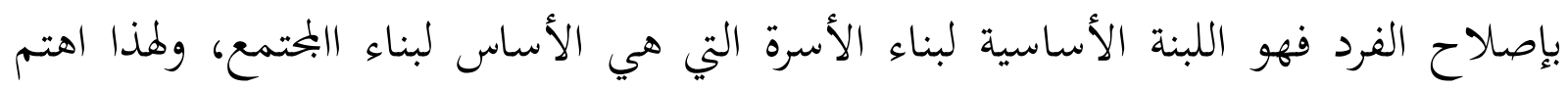
الإسلام براعاية الولد وعمل على إعدادهم إعدادا صالحا وتحصينهم من خطر المعصية والجريمة لماني

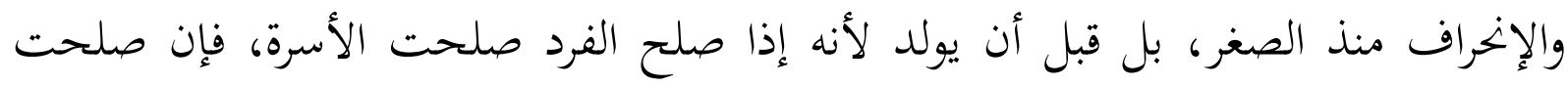
الأسرة صلح البحتمع الذي ينشده الإسلام. ولما كان معلوما ان الحفاظ على حقوق الناس وأنفسهم وأعراضهم من آكد الواجبات

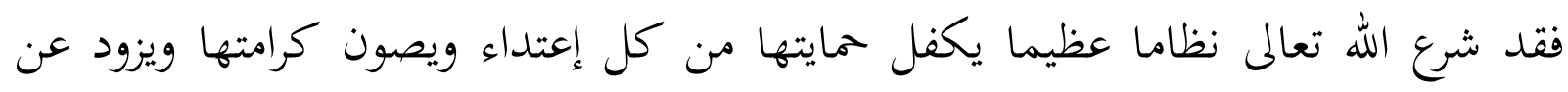

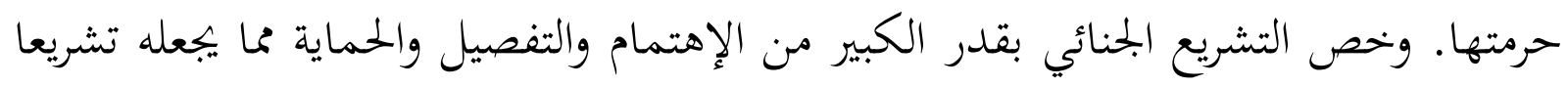

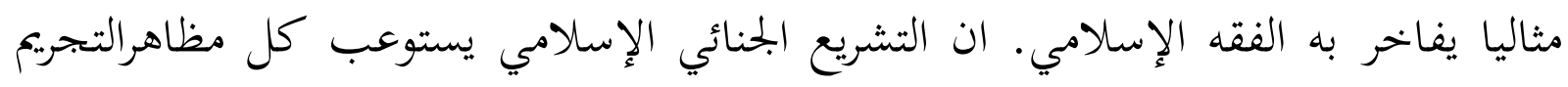
التي فرضتها الأنظمة الوضعية المستحدثة. ولقدأقر الله للإنسان حقوقا يجب أن تراعى، وواجبات يجب أن تؤدى. وهذه الحقوق الحقان

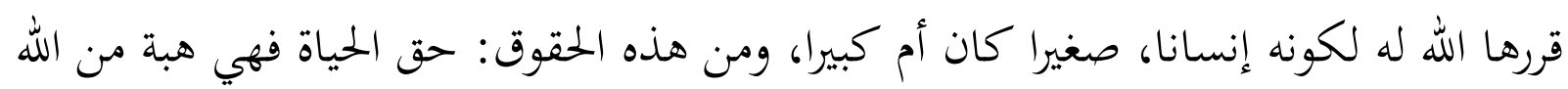

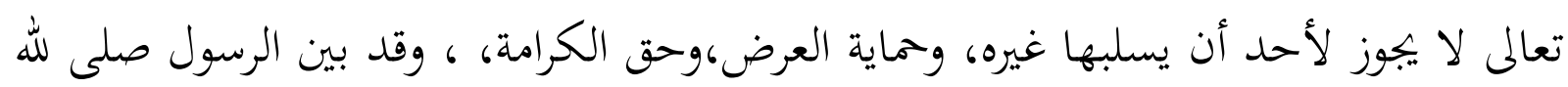

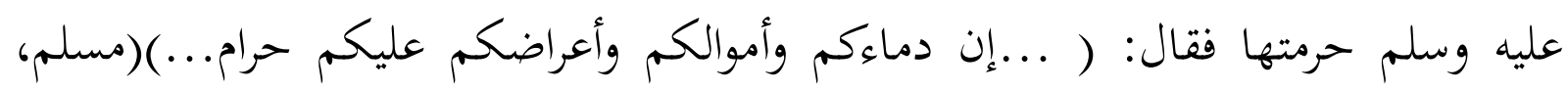
1991، صفحة 1306)وكذا حق التعلم، وحق التفكير ، وحق التدين، وحق التملك وراك

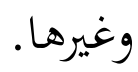
لذلك أوجب حدودا وعقوبات على من اعتدى على هذه الحقوق، فمن اعتدى على إعلى حق الحياة يقتل قال تعالى ومن اعتدى على حق العرض يجلد، ومن اعتدى على على حق اعلى المال 
تقطع يده ومن اعتدى على غيره في حق دون هذه الحقوق يعزر بما يراه القاضي مناسبا.هذا

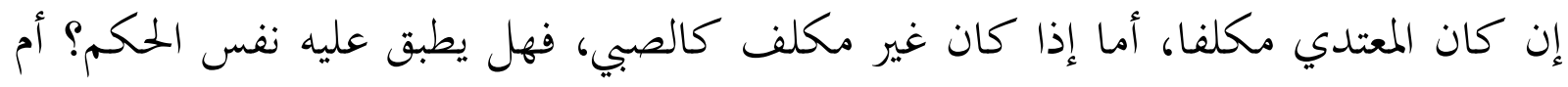

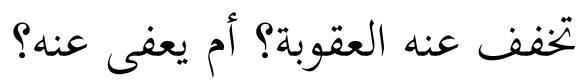
ووجود الأطفال حولنا حاليا فهي بحاجة للحصول إلى الإهتمام،خاصة فيما يتعلق بسلوكهم التي خارجة عن السيطرةلأن ظاهرة انخرافهم تعد من الظواهر الاجتماعية السلبية

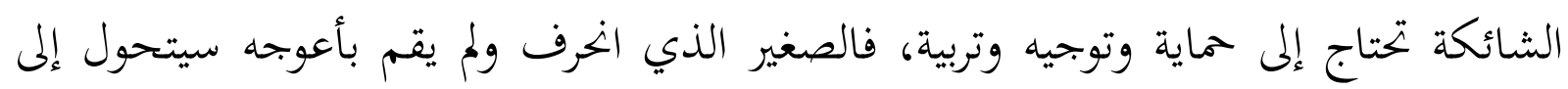

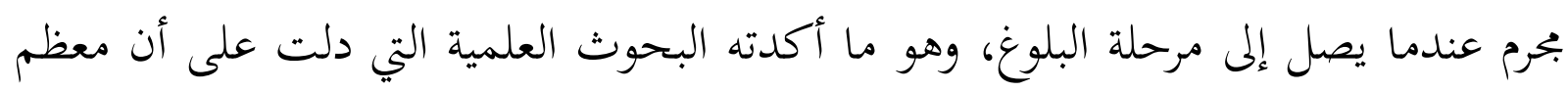
الجخرمين البالغين بدأوا حياقم الجنائية منذ الحداثة. وقد ازداد الآن انخراف الأطفال وتصرفات سيئة تصدر عنهم وسلوكات ضارة بهم وبمجتمعهم، كالمخدرات والسرقة وجرائم الجرح والضرب حتى جريمة القتل، وسيركز هذا البحث

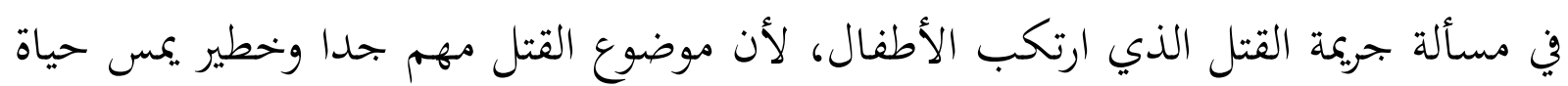

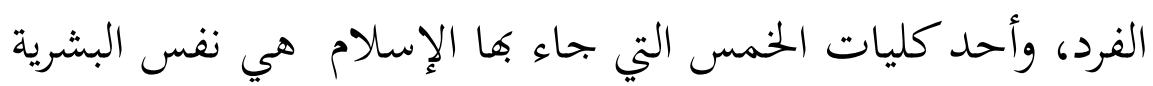

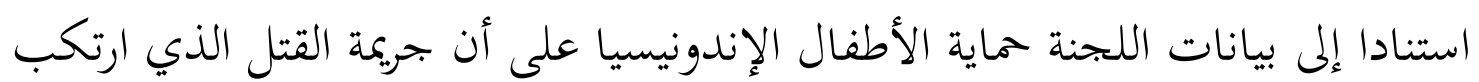
صغر السن من خلال الخمس سنواتلمنقضية (من 2011 إلى 2016) وصلت إلى 264 حالة(KPAI, 2018). هذه البينات تدل على أن جريمة القتل التي ارتكب عليها الأطفال مازال موجودا في إندونيسيا.فمن الواجب للحكومة في البحث عن الوسائل الملائمة لحماية هذه الفئة الضعيفة وحماية البحتمعمن أذاهم وإعادة إدماجهم في المجتمع. مما سبق فاهتم الباحث بدراسة موضوع "أثر صغر السن في مسئولية جريمة القتلدراسة مقارنة بين الفقه الإسلامي والقانون الإندونيسيا". تعريفصغر السن لغة 
(صغر) الصاد والغين والراء أصل صحيح يدل على قلة وحقارة. من ذلك الصغر: ضد الكبر. والصغير: خحلاف الكبير. والصاغر: الراضي بالضيم صغرا وصغارا. ويقال: أصغرت

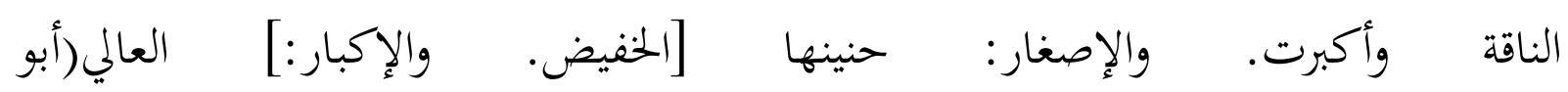

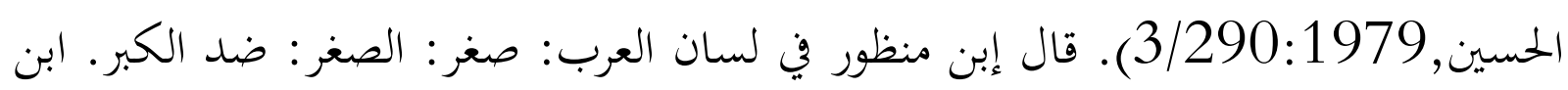
سيده: الصغر والصغارة خلاف العظم، وقيل: الصغر في الجرم، والصغارة في القدر؛ صغر صغارة وصغرا وصغر يصغر صغرا؛ بفتح الصاد والغين، وصغرانا؛ كلاهما عن ابن الأعرابي: فهو صغير وصغار، بالضم، والجمع صغار. قال سيبويه: وافق الذين يقولون فعيلا الذين يقولون

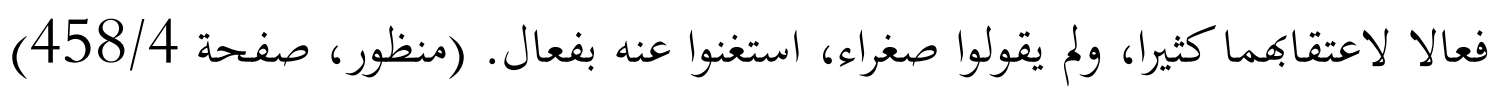
وفي حديث عمرو بن دينار قال: قلت لعروة: كم لبث رسول الله، صلى الله عليه وسلم، بمكة؟ قال: عشرا، قلت: فابن عباس يقول بضع عشرة سنة، قال عروة: فصغره أي استصغر سنه عن ضبط ذلك، وفي رواية: فغفره أي قال غفر الله له، وسنذكره في غفر أيضا. والإصغار من الحنين: خلاف الإكبار؛ قالت الحنساء:فما عجول على بو تطيف به، ... لها حنينان: إصغار وإكبار فإصغارها: حنينها إذا خفضته، وإكبارها: حنينها إذا رفعته، والمعنى لها حنين ذو صغار وحنين ذو كبار . وأرض مصغرة: نبتها صغير لم يطل.

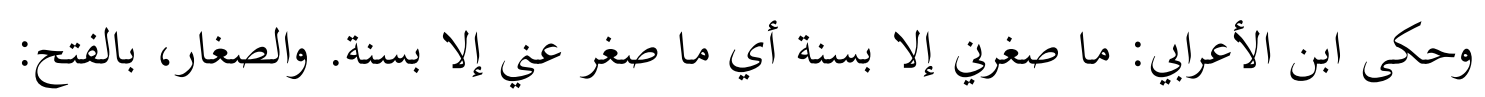
الذل والضيم، وكذلك الصغر، بالضم، والمصدر الصغر، بالتحريك. يقال: قم على صغرك وصغرك. الليث: يقال صغر فلان يصغر صغرا وصغارا، فهو صاغر إذا رضي بالضيم وأقر به.

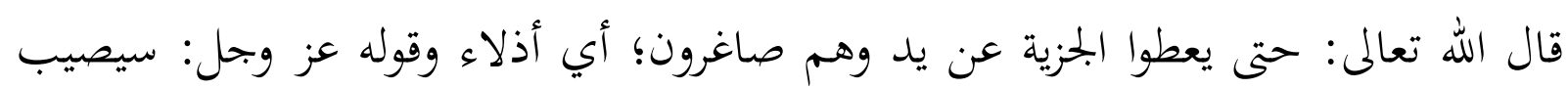

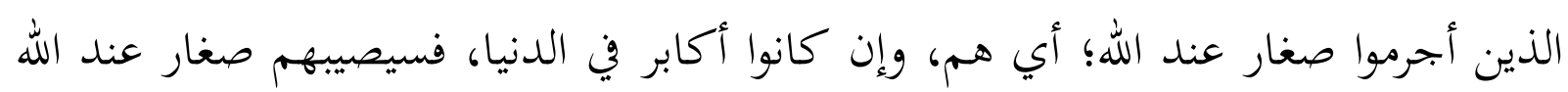

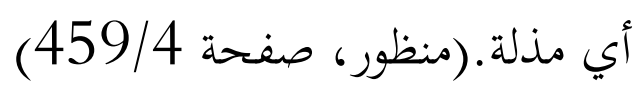


مما سبق يتبين لنـا أن صغر السـن تطلق على مـن قل سـنه أو قل حجمـه فهو

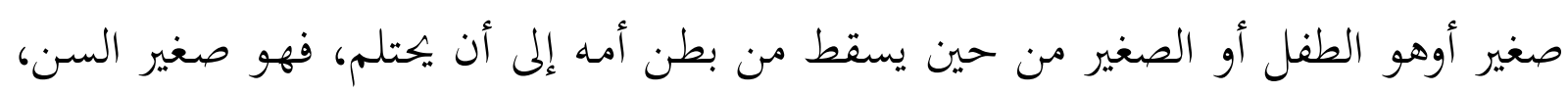
أي دون سن البلوغ.

\section{تعريف صغر السن في الفقه الإسلامي}

لقد اهتم الفقهاء بدراسة أحكام صغار السن، واستعملوا بالألفاظ الصبي والصغير الصغاري

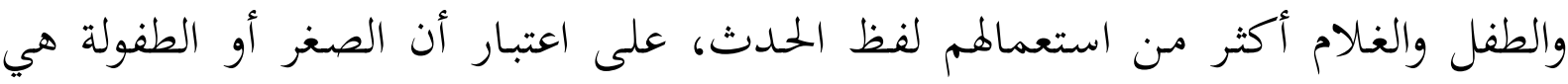

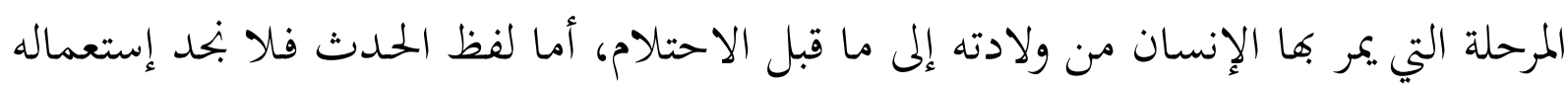

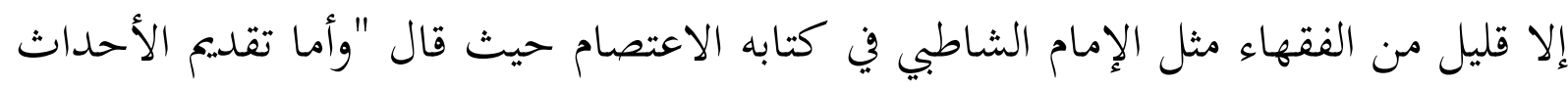
على غيرهم من قبيل ما تقدم في كثرة الجهل وقلة العلم ، كان ذلك التقديم في رتب العلم

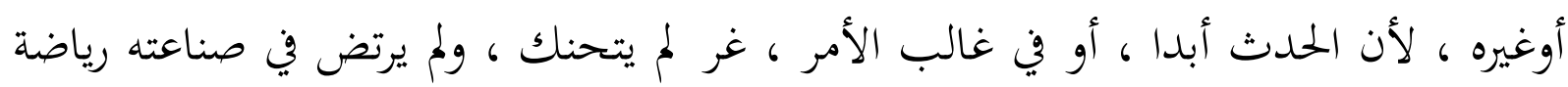

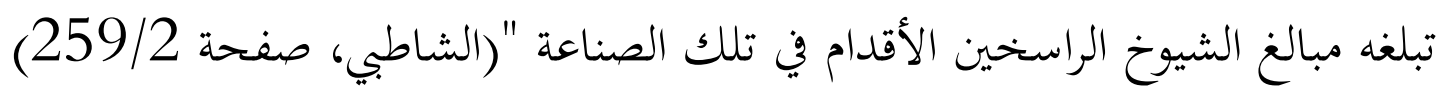

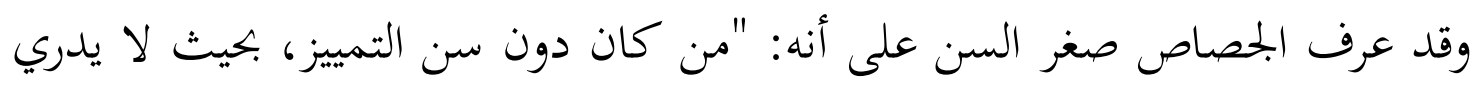

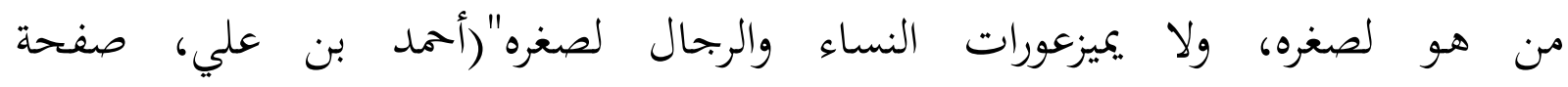

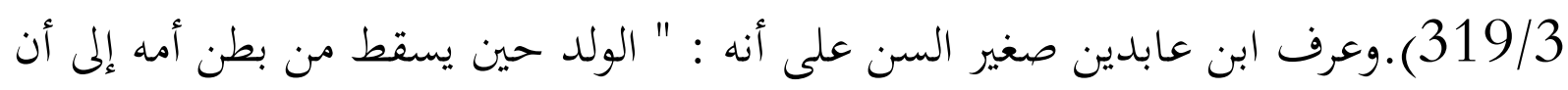

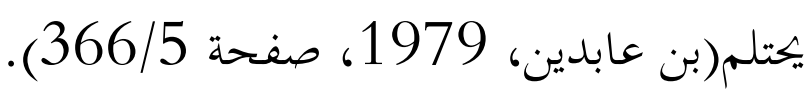

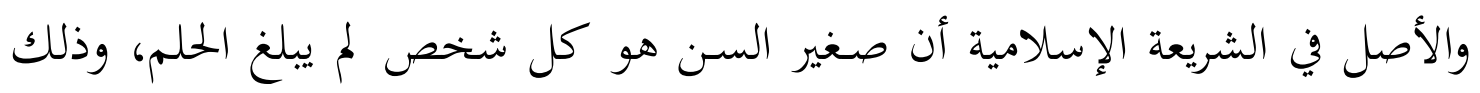

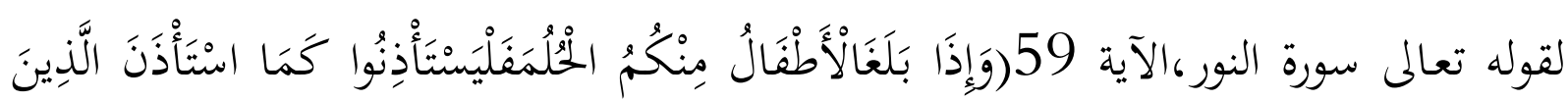

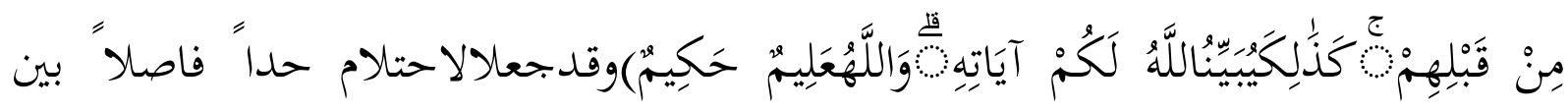
مرحلتي الطفولة ومرحلة البلوغ والتكليف لكون الاحتلام دليلاً على كمال العقل وهو مناط التكليف، فهو قوة تطرأ على الشخص وتنقله من حالة الطفولة إلى حالة الرجولة، وبلوغ الحلم 
يعرف بظهور العلامات الطبيعية لدى المرء، فهي عند الذكر بالاحتلام وعند الأنثى بالحيض

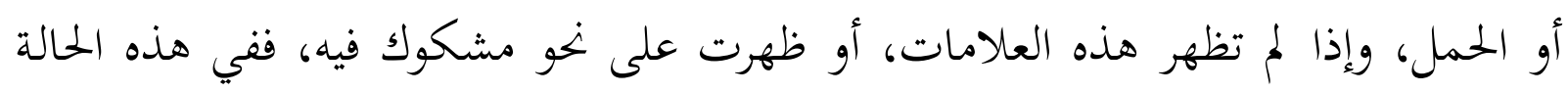

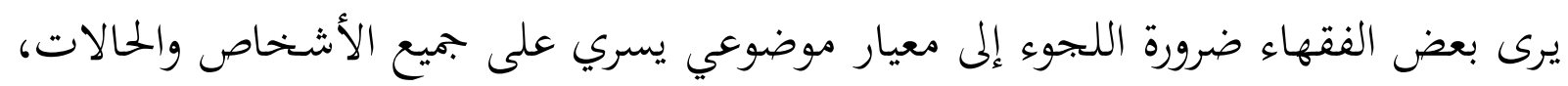

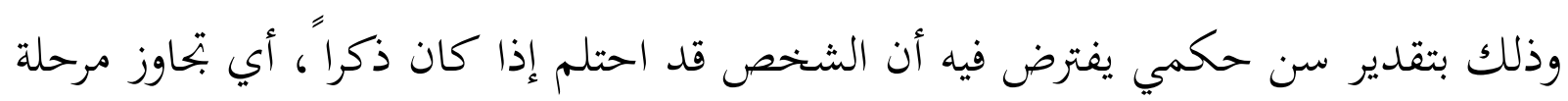

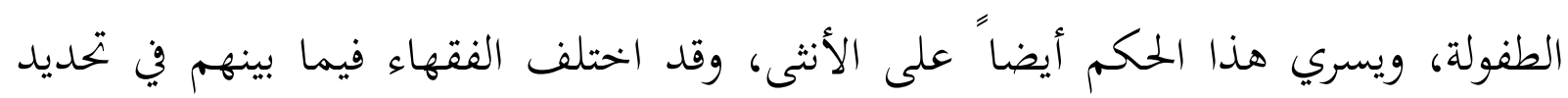

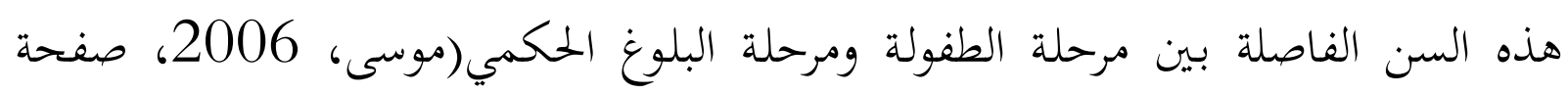

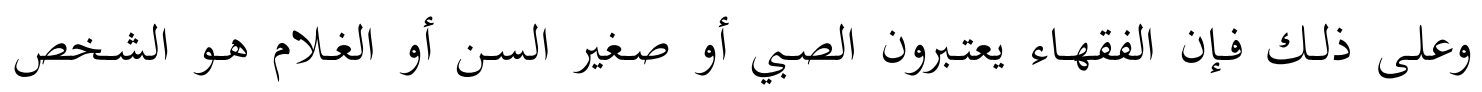

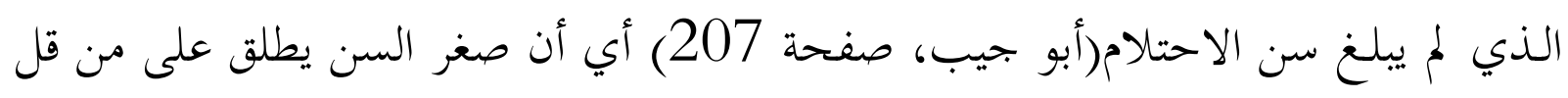

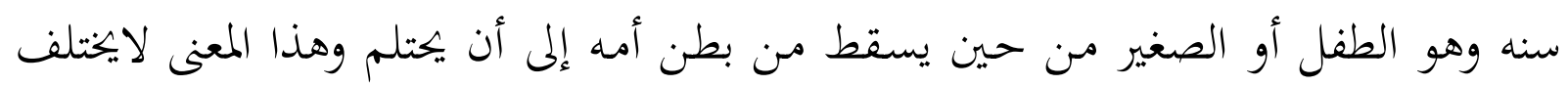

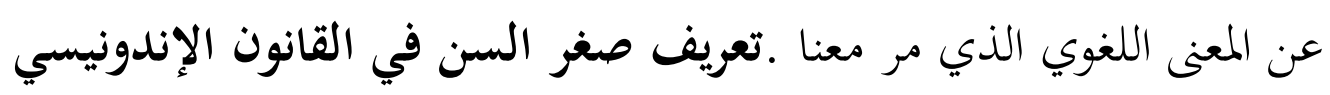
قد اختلف تعريف صغير السن في القانون الإندونيسي، فنصت المادة 330 القانون الجنائي الإندونيسي بأن الطفل هو كل من لم يبلغ واحد وعشرون سنة ولم يتزوج، ونصت

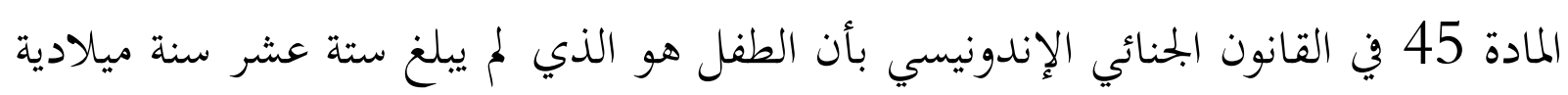

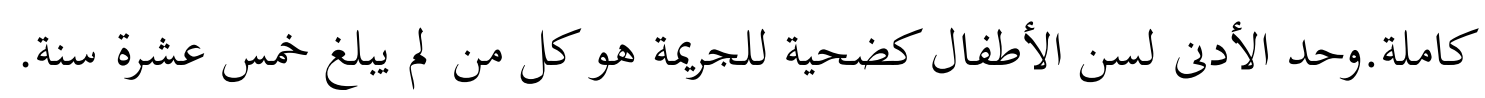
نصت القانون لحماية الطفل رقم 23 لسنة 2002 بأن الطفل هو كل من لم يبلغ تماني عشرة سنة بما في ذلك الجنين في بطن أمه. ونصت القانون نظام القضائي للطفل رقم

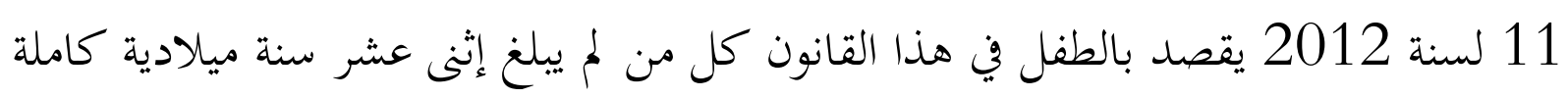
ولم يكتمل ثمانية عشر في ارتكاب الجريمة. 
وفيقرارامكمةالدستورية رقم : 2010/VII-PUU/1، تاريخ 24 فيبراير 2011،

في نظام القضائي للطفل لمحمة الدستورية أن العبارةبثمانيةسنوات في مادة 1 رقم 1، مادة 4 أية 1 ومادة 5 أية UU 1 رقم 3 لسنة 1997 في بحال القضاء للطفل مخالفة للقانون

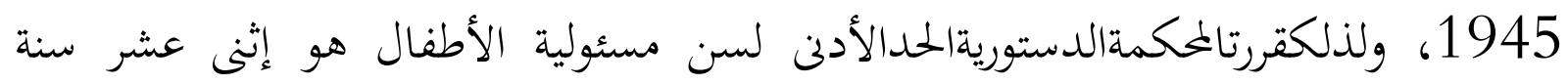
ميلادية كاملة.

\section{مسئولية صغر السن في الفقه الإسلامي} رأى بعض الفقهاءفي الشريعة الإسلامية بأن للصبي منذ ولادته إلى بلوغه يمر في الإني

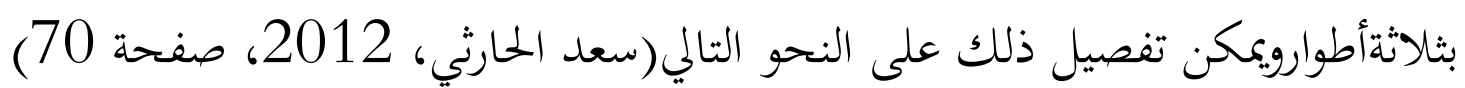
الطور الأول: قبل سن التمييز(كبيسي، 1986، صفحة 70):

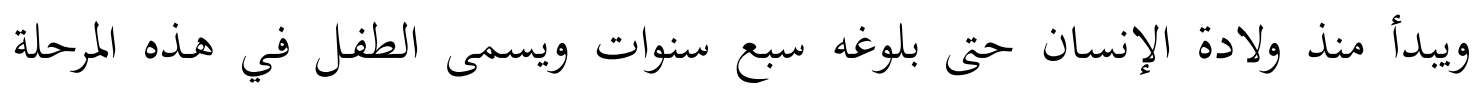

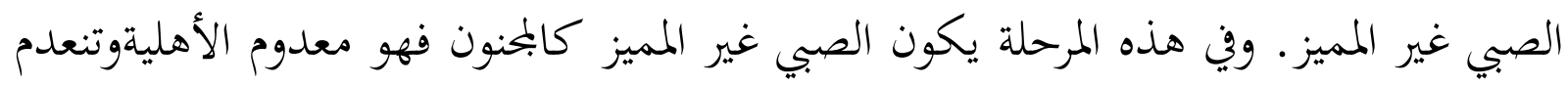

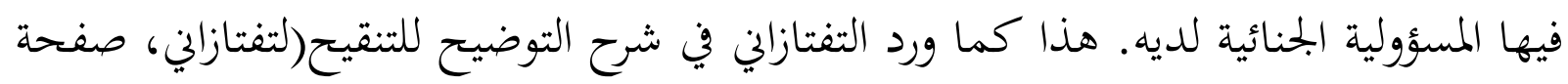
.(168/1 قبل سن التمييزفاقد الأهلية أي أهلية الأداء وعديم الإدراك والتمييز، ولاتقوم

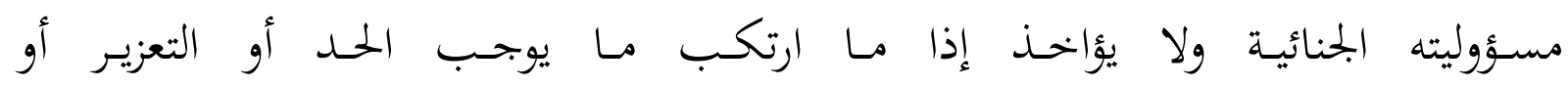
القصاص(عبدول، الصفحات 355, 755/2)حتى ولو كانالقتيل مورثه لايحرم الطفل

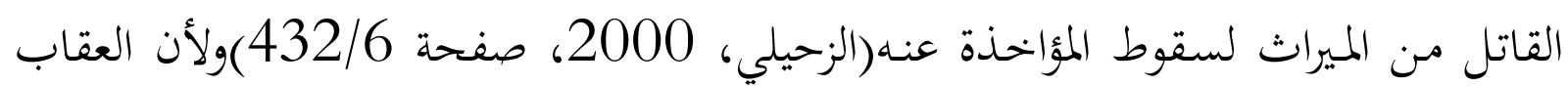
جزاء جناية وفعل الصبي لايوصف بذلك(الكاساني، 1982، صفحة 234/7) 
فالصغير غير المميز لايفقه معاني الأفعـال ولايقصدها، لذذلك فهو غيرمسؤول

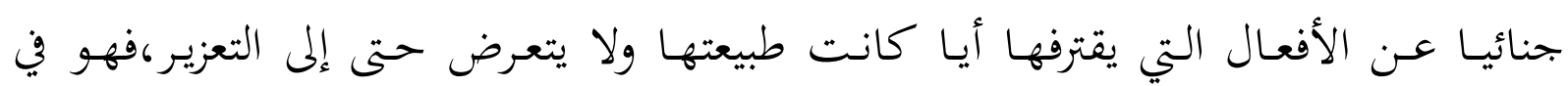

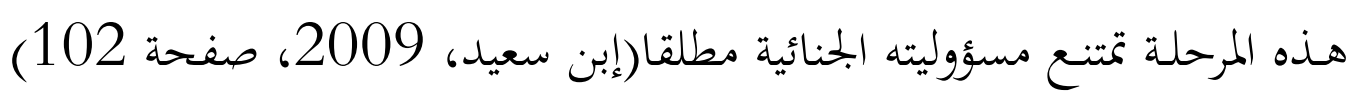
غير أن انعدام مسؤوليته الجنائية في هذه المرحلة لايسقط حق الغير، إذ أن أن مسؤوليته

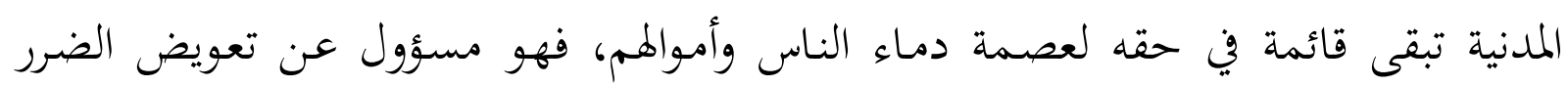

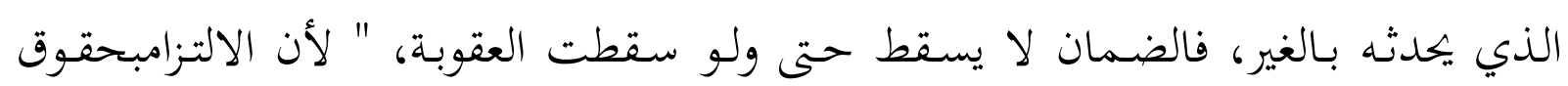

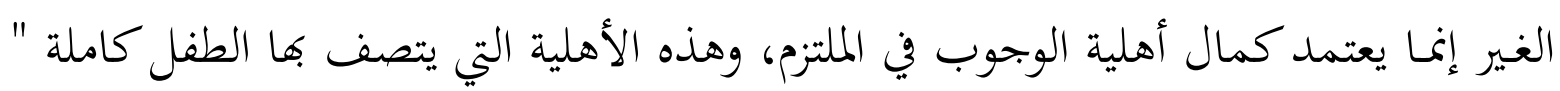

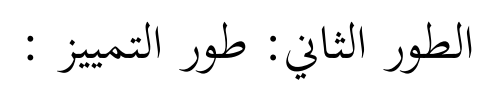

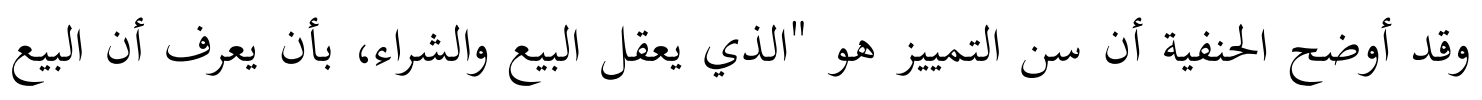

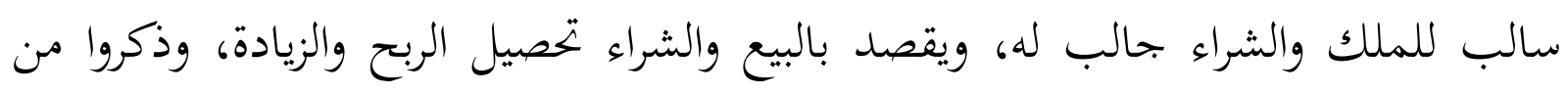

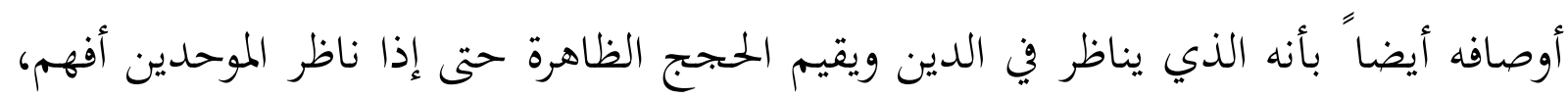

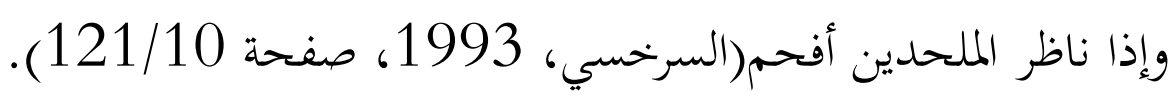

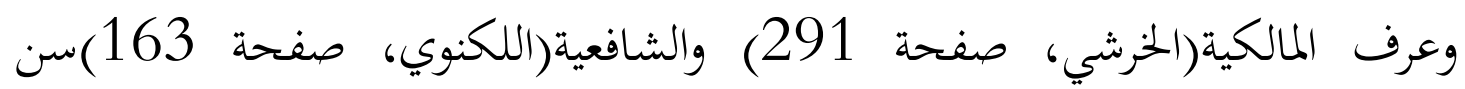

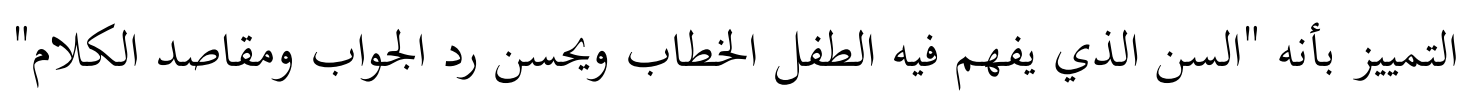

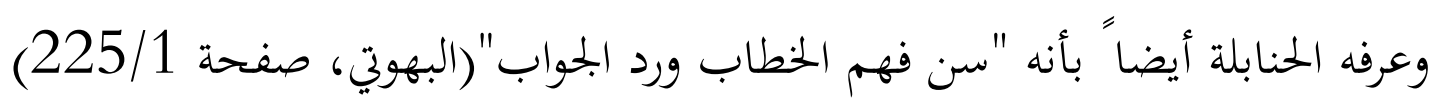

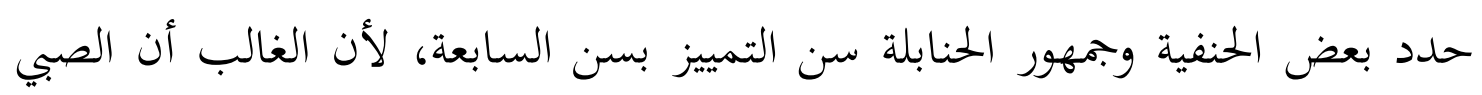

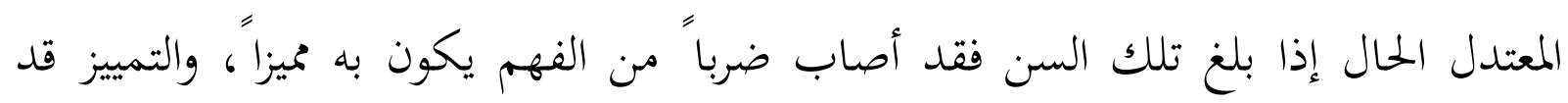

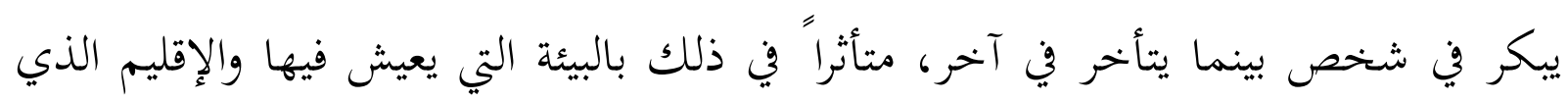

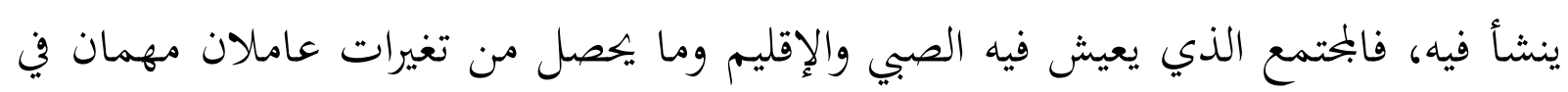

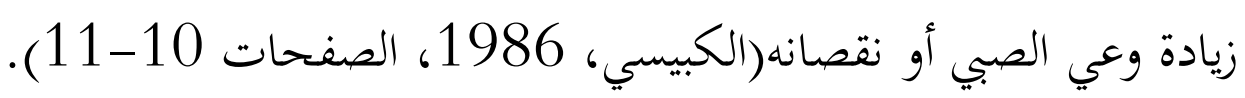


وقد حـد الفقهاء التمييز بسبع سنوات، لأنه لايمكن تصسور تمييز قبل هـذه

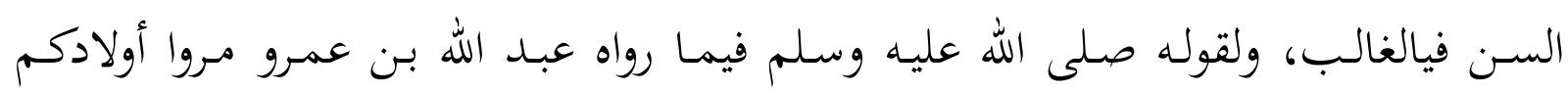

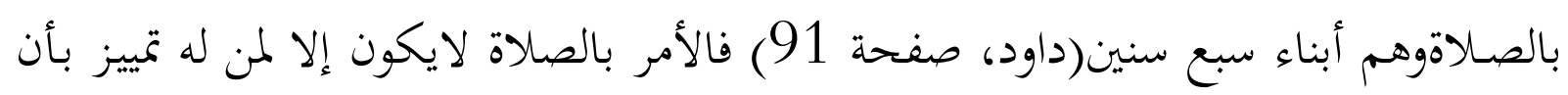

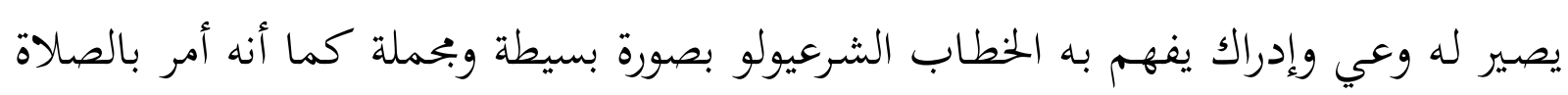

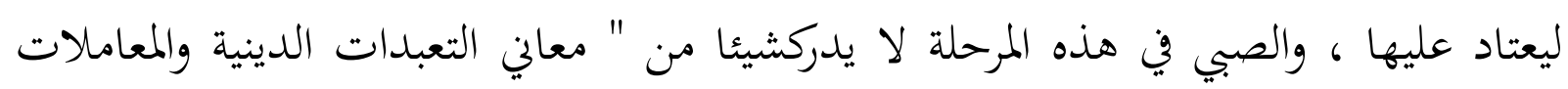
المدنية .. وإن كان يدرك ويميز بعضالأمور الطبيعية(أممد الزرقاء، صفحة

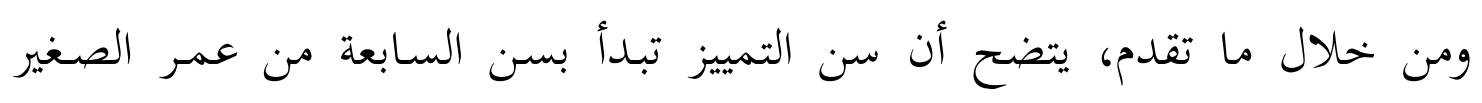

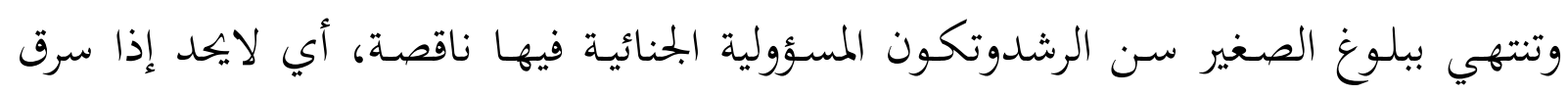

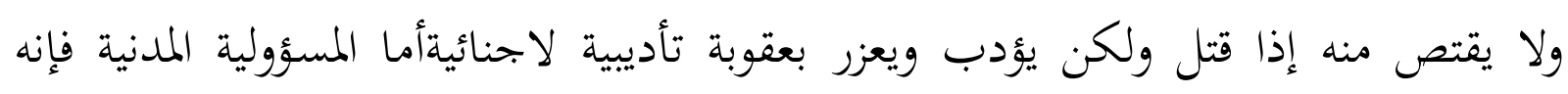

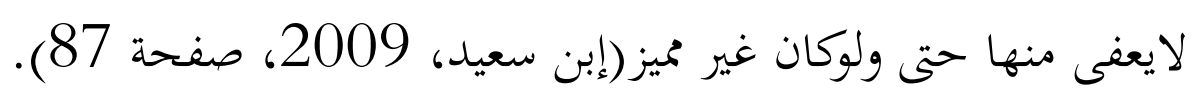

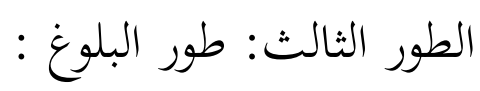
كان التكليف في الشرع متعلق بالعقل، فقال رسول الله صلى الله عليه وسلم:"رفع

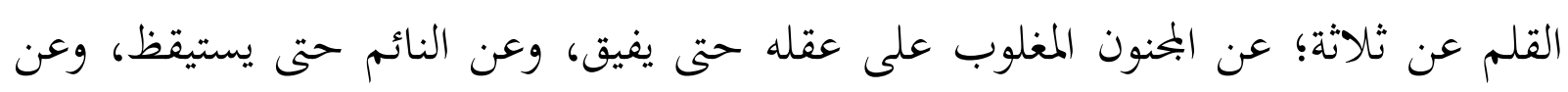

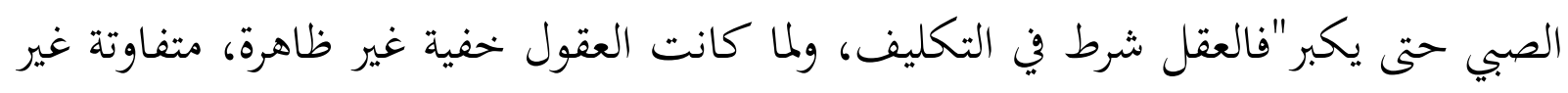

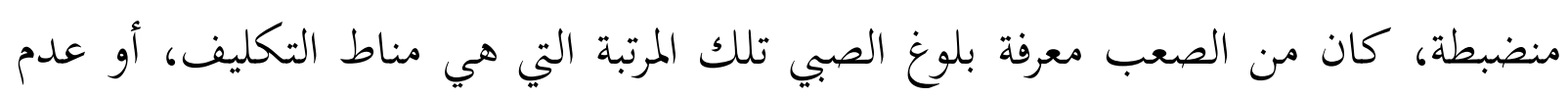

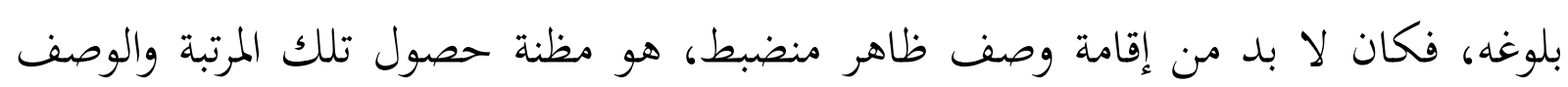

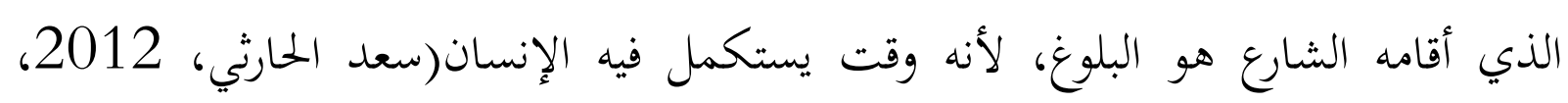
صفحة 84). ففي هذه المرحلة يكون الشخص مسؤولا مسؤولية جنائية كاملة عن جرائمه أيا

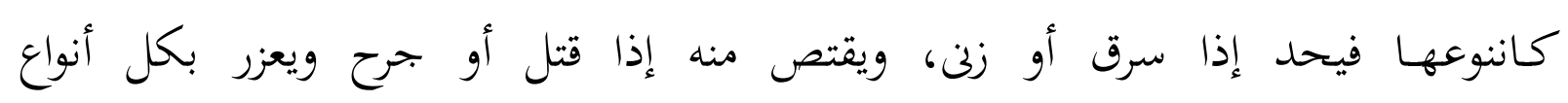

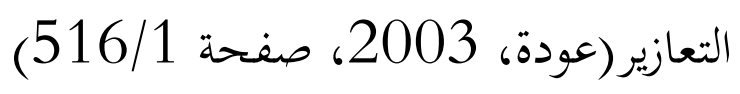


ويمكن توضيح العلامات المختلفة للبلوغ على النحو التالي: 1. الإنزالهو خروج المني يقظة أو مناماً بجماع أو غيره.

2. الإنبات: والمراد به نبات الشعر الخشنالذي استحق أخذه بالموس على العانة، ولا اعتباربالزغب الضعيف لأنه ينبت للأطفال(كبيسي، 1986، صفحة 18). وإن اختلف العلماء في إعتبار الإنبات من علامة البلوغ 3. السن بالنسبة للذكر:وقد احتلف العلماء في ذلك، كما يلي

لالخمس عشرة سنة، وبه قال الشافعية، والحنابلة، وهو القول المشهورلأصحابمالك، وبه قال كثير من فقهاء العامة غير أصحاب المذاهب.

$$
\text { ل سبع عشرة سنة، أو ثماني عشرة وهو قول أبي حنيفة. }
$$

لأنه لا حد للبلوغ بالسن، وإلى هذا القول ذهب مالك، وداود الظاهري.

$$
\text { 5. } 4 \text { 4. الحيض عند المرأة }
$$

محا سبق يتضحبأن مسؤولية الجنائية في الشريعة الإسلامية ترجع إلسالتمييزوالإختيار، والتمييز يتدرج تبعاً للمرحلة من العمر التي يمر بها الإنسان منذولادته إلى أن يكتمل تمييزه. مسئولية صغر السن في القانون الإندونيسيا

نصت القانون لمحكمة الأحداث رقم 3 لعام 1997 بأن سن مسئولية الجنائية للطفل هو ثمانية سنوات مالم يبلغ ثمانية عشر سنة ولم يتزوج. تحديد سن الثمانية إلى سن ثمانية عشر

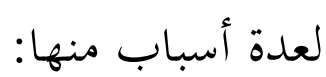

1. الغالب أن الصبي معتدل الحال ولديها بالفعل شعور بالمسؤوليةإذا بلغ تلك السن(Gultom, 2006, p. 84) 


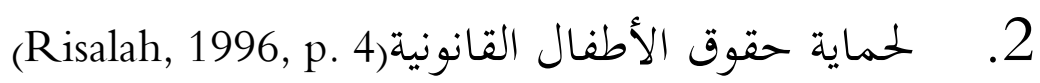
3. ان الطفل إذا بلغ تلك السن يمكن أن يكون مسئولالأفعاله اجتماعية والنفسية والتربوية) (Lihat Penjelasan Pasal 4 Ayat 1 UU Pengadilan Anak

لكنه في النهاية يتم اختبار القانون لمحكمة الأحداث رقم 3 لعام 1997 في

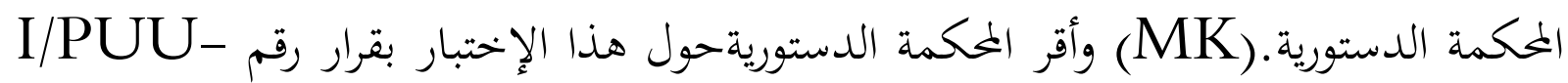
بقبول جزئية من عريضة مقدم الطلب، وفي ذلك القرار رأى المحكمةالدستورية بأن الحدالأدنى لسن مسئولية الأطفال هو إثنا عشر سنة ميلادية كاملة.

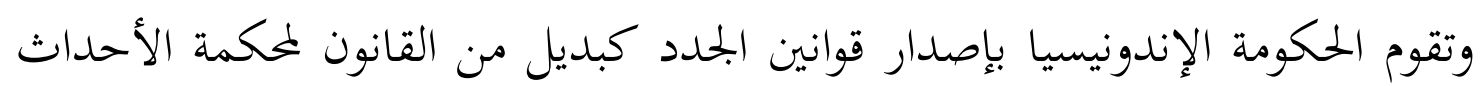
رقم 3 لعام 1997 التي تعتبر أكثر توافقا مع المثل العليا الدولية لحماية الأطفال هي القانون لنظام المحكمة الأحداث الجنائية رقم 11 سنة 2012 التي تحدد الحد الأدنى لسن المسؤولية الجنائية اللطفل ان يكون 12 (اثنا عشر) سنة ، ولم يبلغ ثمانية عشر سنة.

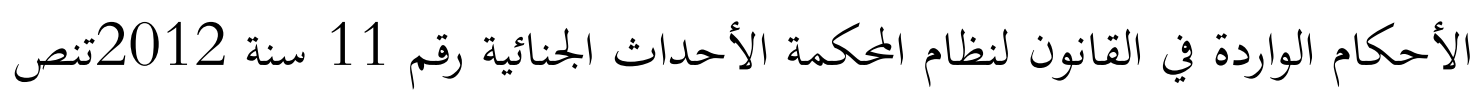
بأن الطفل الذي لم يبلغ اثنا عشر سنة من عمره إذا ارتكب جريمة أو يزعم بارتكب الجريمةفالمققون الجنائينوالمستشار الجمعية يتخذون القرار لأمرين: 1. إعادة الطفل إلى آباءه / وأوليآه 2. إدراجه في برامج التعليم والتدريب والتوجيه من الجهات الحكومية أو الجهات الرعاية الاجتماعية على الأكثر 6 (ستة) أشهر.

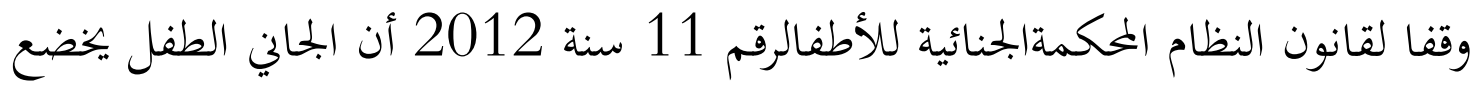
لنوعين من العقوبات هي عقوبة الجزاءات(tindakan)للجاني الطفل الذي لم يبلغ 14 (أربعة عشر) سنة من عمره كما نصت مادة 69 أية 2 القانون الإندونيسيا Lihat ketentuan Pasal) 
69 Ayat 2 UU SPPA) وعقوبة الجنائية للجاني الطفل الذي تتراوح أعماره بين 14 سنة إلى 18

محا سبق يتضحبأن سن المسؤولية الجنائية للطفل في القانون الإندونيسيا هو الذي يبلغ 14 سنة إلى 18 سنة من عمره كما ورد في القانون النظام المحكمةالجنائية للأطفال رقم 11 سنة 2012 وكما نصت المادة 69 أية 2 في القانون الإندونيسيا. أثر صغر السن في جريمة القتل في الفقه الإسلامي القتل هو الفعل المزهق أي القاتل للنفس أو المميت ، أو هو فعل من العباد تزول به الحياة(ابن الهمام ، 1987، صفحة 244/8) ، أي أنه هدم للبنية الإنسانية(الزحيلي، 2000، صفحة 5813/7) وقد قسم العلماء القتل إلى ثلاثة أنواع النوع الأول: القتل العمد وهو الذي يقصد معه الشخص إزهاق الروح أي يكون له نية الإماتة(إبن سعيد، 2009، صفحة 120).هو قصد الفعل العدوان والشخص بما يقتل غالباً، جارحٍ، أو مثقل، مباشرة، أو تسبباً، كحديد وسلاح وخشبة كبيرة، وإبرة في مقتل، أو غير مقتل كفخذ وألية إن حدث تورم وألم واستمر حتى مات، أو كأن قطع إصبع إنسان، فسرت الجراحة إلى النفس ومات. القتل إذا كان عمداً عدواناً جريمة كبرى، ومن السبع الموبقات التي يترتب عليها استحقاق العقاب في الدنيا والآخرة، وذلك بالقصاص، والخلود في نار جهنم؛ لأنه اعتداء على صنع الله في الأرض، وهميد لأمن الجماعة وحياة البمتمع(الزحيلي، 2000، صفحة 5813/7). النوع الثاني:شبه العمد هو قصد الفعل العدوان والشخص بما لا يقتل غالباً، كضرب بحجر خفيف أو لكمة باليد، أو بسوط، أو عصا صغيرين أو خفيفين، ولم يوال بين الضربات، وألا

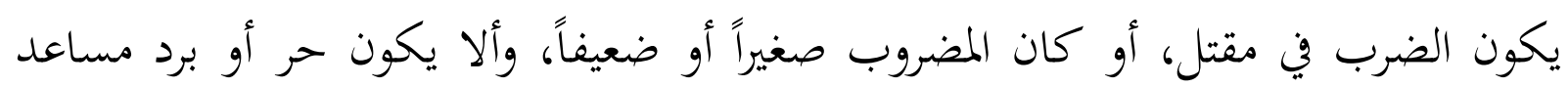


على الهلاك، وألا يشتد الألم ويبقى إلى الموت. فإن كان شيء من ذلك فهو عمد؛ لأنه يقتل

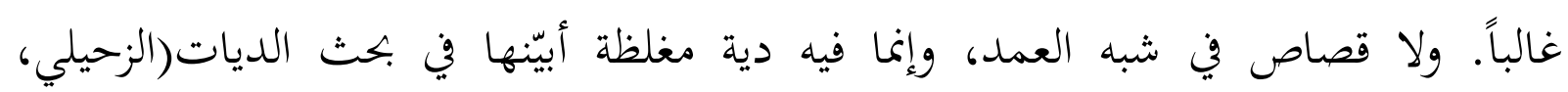
2000، صفحة 5619/7).

النوع الثالث: الخطأ هو القتل الحادث بغير قصد الاعتداء لا للفعل، ولا للشخص، كأن وقع شخص على آخر فمات، أو رمى شجرة أودابة، فأصابت الرمية إنساناً فمات، أو رمى آدمياً فأصاب غيره فمات. فلا يجب عليه القصاص وتحب عليه الدية والكفارة(الكاساني، 1982، الصفحات 133-134)

اختلف الفقهاء إذ ارتكب الصغير جريمة القتل وحده عمد في ثلاثة أقوال: القول الأول :عمد الصغيرخطأ، وهو قول جمهور العلماءمن الحنفيةوالمالكيةوالحنابلة(تيمية، 2005، صفحة 100/34)

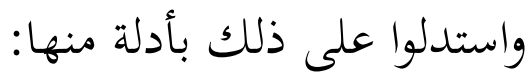
1. قول رسول الله صلى الله عليه وسلم: "رفع القلم عن ثلاثة؛ عن المخنون المغلوب على عقله حتى يفيق، وعن النائم حتى يستيقظ، وعن الصبي حتى يكبر"

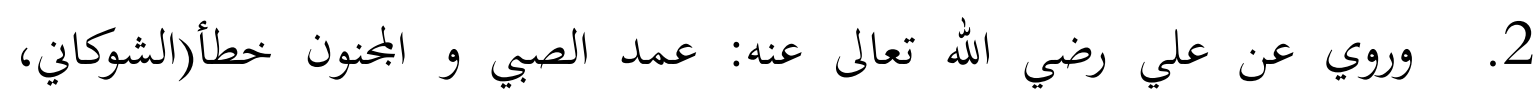

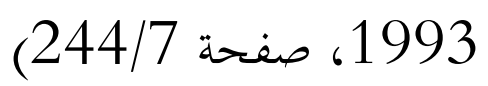

3. يعتبر فعل الصبي في حكم الخطأ لأن الصبي ليس له قصد صحيح(قدامة، 1997، صفحة 481/11)

القول الثاني: عمد الصغير عمد، وهو القول الأظهر والأصح عند الشافعية(النووي،

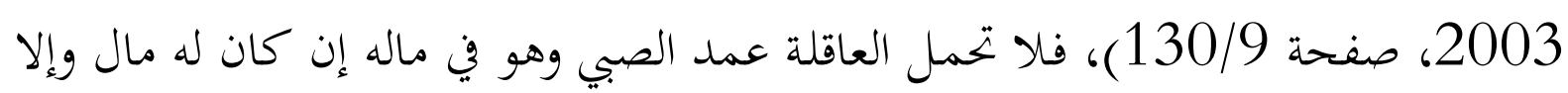

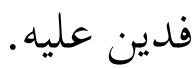




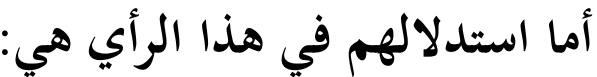

قتل الصبي يجري فيه حكم العمد وإن سقط فيه القود، ولأنه لما كان عمده للكلام في

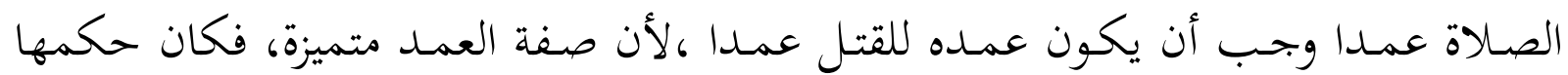
ميزا، ولأن كل من وقع الفرق بين عمده وخطإِ في العبادات، وقع الفرق بمدات بينهما في الجنايات كالبالغ العاقل(النووي، صفحة 25/7) وقد رد العماء على هذا القول بقولم: لا نسلم تحقق العمدية من الصبي فالعمدية

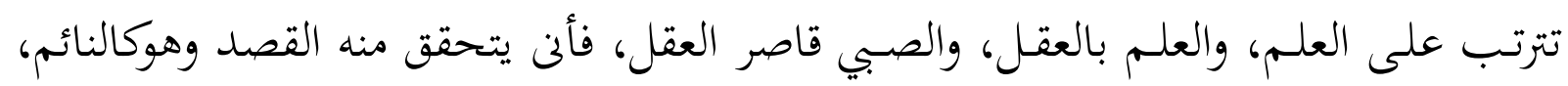
وحرمان الصبي من الميراث عقوبة، وهو ليس عقوبة والكفـارة كاسمها ستارة، ولا ذنب تستره

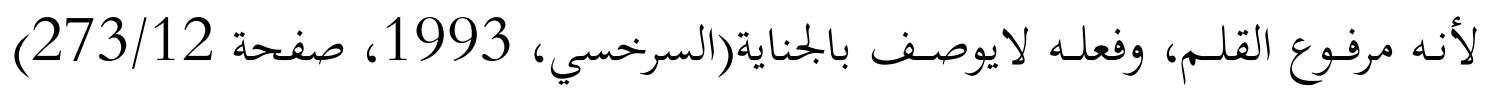
القول الثالث:لايعتبر جرم الصغير عمدا ولا خطأ، إنما هو هدر ففعله كفعل البهيمة

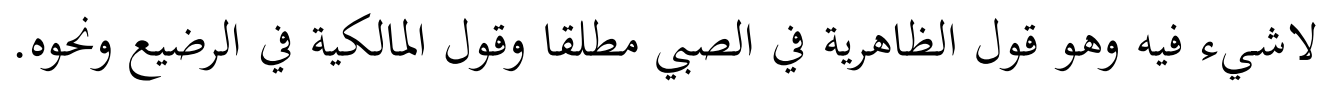

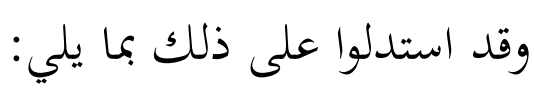
1. قول رسول الله صلى الله عليه وسلم: "رفع القلم عن ثلاثة؛ عن المجنون المغلوب على عقله حتى يفيق، وعن النائم حتى يستيقظ، وعن الصبي حتى الهى يكبر " 2. ماجاء في كتاب عمر بن عبد العزيز رضي الله عنه عن عمر بن الخطاب رضي الله

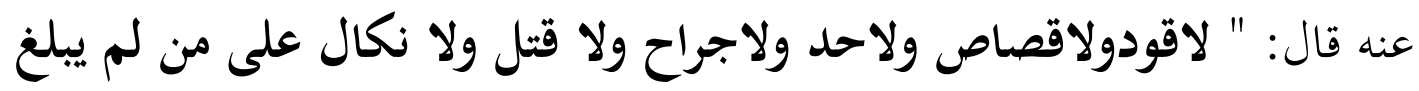

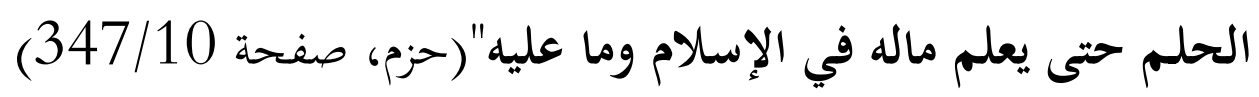

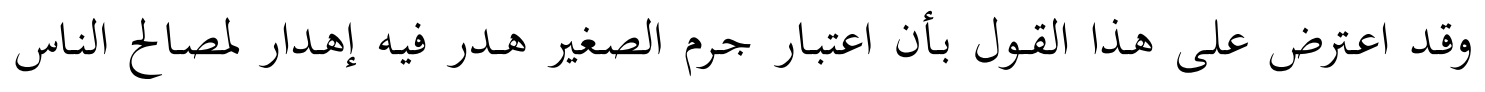

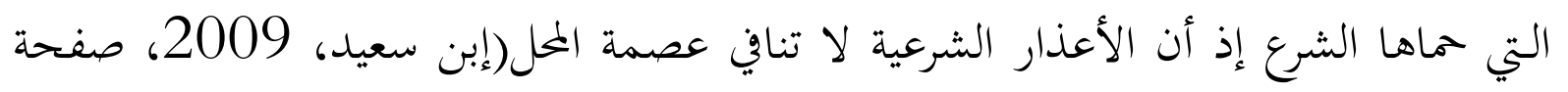




\section{أثر صغر السن في جريمة القتل في القانون الإندونيسيا}

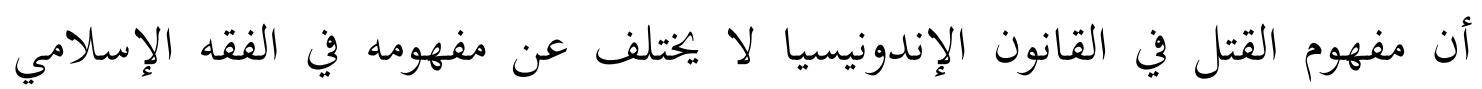
وعرفه القانون الجنائي الإندونيسيا بأنه "إزهاق روح إنسان عمدا".

الأحكام الجنائية المتعلقة بالجرائم القتل ترد في الكتاب II من الفصل XIX ، الذي

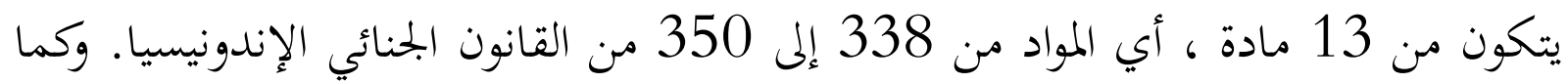
أن القتل في القانون الإندونيسيا قد يكون عمدا وقد يكون خطأ وانقسم قتل العمد في القانون الجنائي الإندونيسيا إلى ثلاثة أقسام منها: 1. قتل العادية هذه الجريمة تنص المادة 338 من القانون الجنائيالإندونيسيا. أما

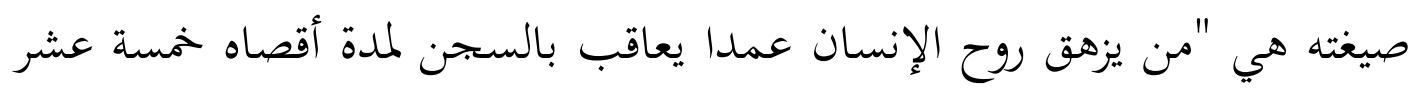
سنة". وتكون عناصر القتل العادي كما يلي: أ. أن يتعمد الجاني في هذه الجريمة والعمدية يجب أن تنشأ على الفور. ب. أن يكون القتل نتيجة لفعل الجاني. 2. القتل مع الترجيه(Gequalificeerde Doodslag)هذه الجريمة تنص المادة 339 من من القانون الجنائيالإندونيسيا. أما صيغته هي: "القتل الذي يتبع (gevold) أو يرافقه (vergezeld)

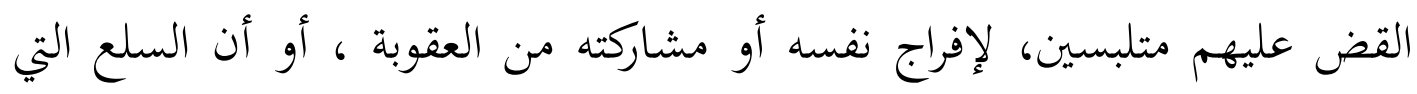

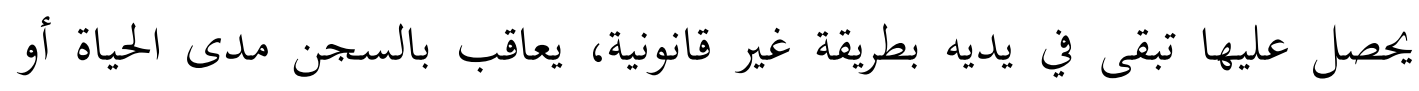
السجن المؤقت لمدة عشرين عاما." 
3. القتل مع التخطيط/ تمالؤ(Moord)هذه الجريمة تنص المادة 340 من القانون الجنائيالإندونيسيا. أما صيغته هي: "من يتعمد ويخطط مقدما في إزهاق روح الآخر

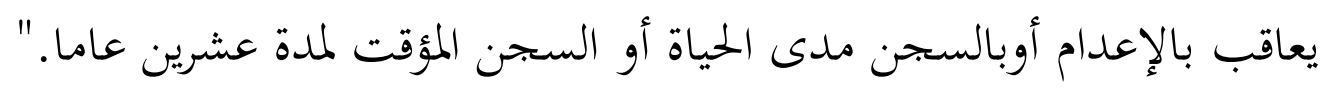
4. القتل بإذن المقتول هذه الجريمة تنص المادة 344 من القانون الجنائيالإندونيسيا.

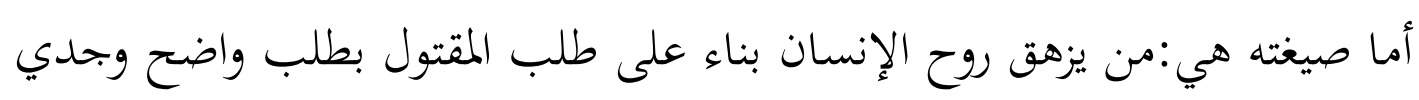
عمدا يعاقب بالسجن لمدة أقصاه إثنا عشر سنة.

اما قتل غير العمد/الخطأ فتنص المادة 359 القانون الجنائي الإندونيسيا على أنه: "

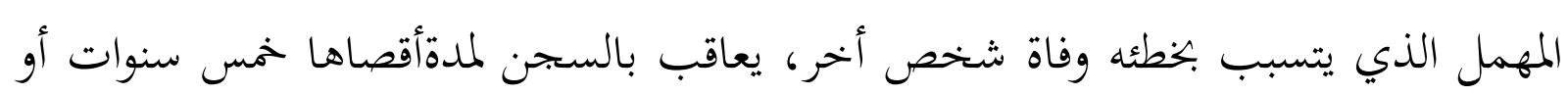
الحبس لمدة أقصاها سنة واحدة"

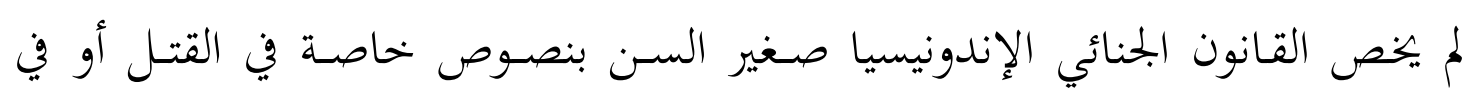

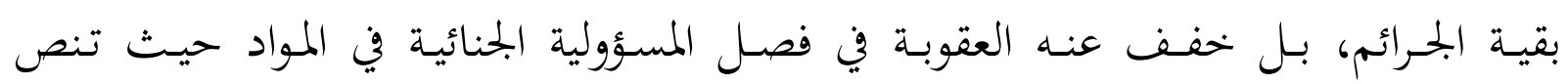

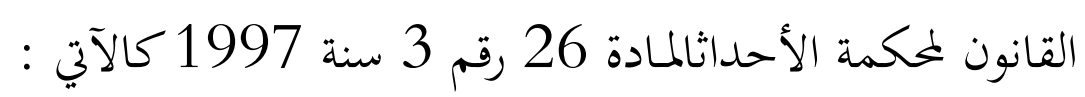

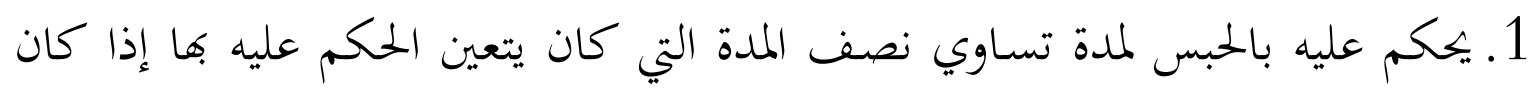
بالغا 2. إذا كانت العقوبـة التي تفرض عليه هي الإعـدام أو السـحن المؤبد فإنه يحكم عليه بعقوبة الحبس لمدة أقصاها عشر سنوات.

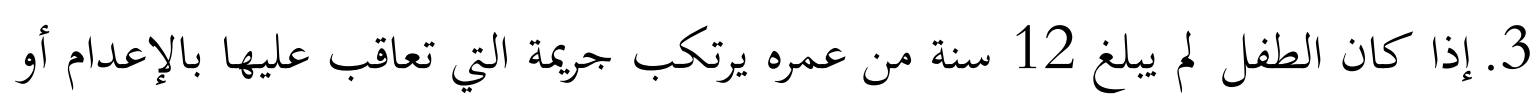

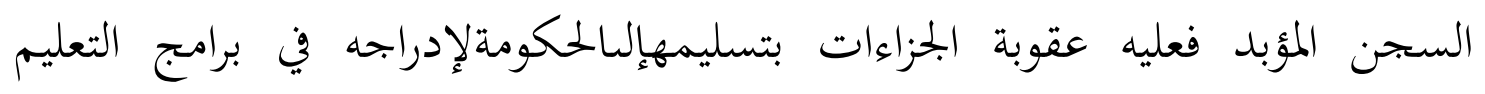
والتدريب والتوجيه. 
4. إذا كان الطفل لم يبلغ 12 سنة من عمره يرتكب جريمة التي لم تعاقب عليها بالإعدام أو السجن المؤبدفعليه أحد من عقوبة الجزاءات.

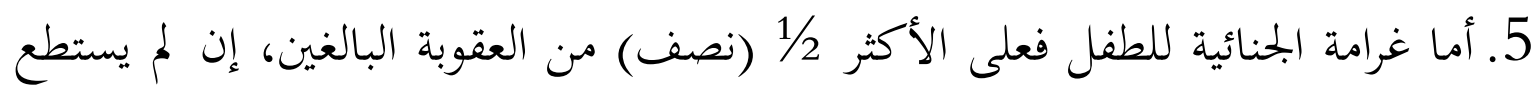
بدفع الغرامة ، فيستبدلها بتدريب عمل الإلزامي. فالصغير الذذي ارتكـب جريمة القتل عمـدا تطبق عليه العقوبـات المـذكورة في المادة 338، 339, 340 لكن يخنف عنه العقوبة كما وردة في القانون لمحكمة الأحداثلمادة 26

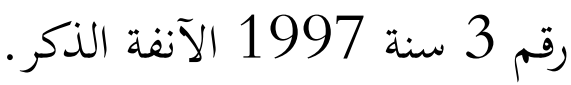

الخاتمة

موازنة بين الفقه الإسلامي والقانون الإندونيسيا

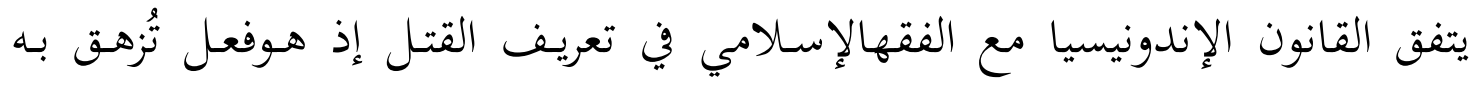

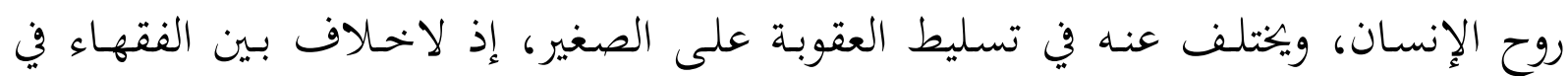

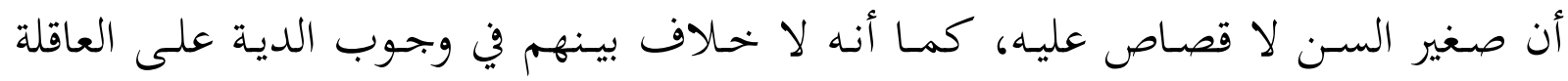

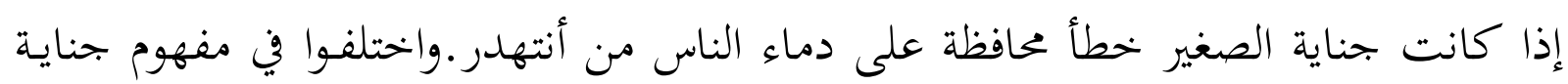
الصغير العمد، وفي وجوب الدية هل هي على العاقلة أم على الصغير.

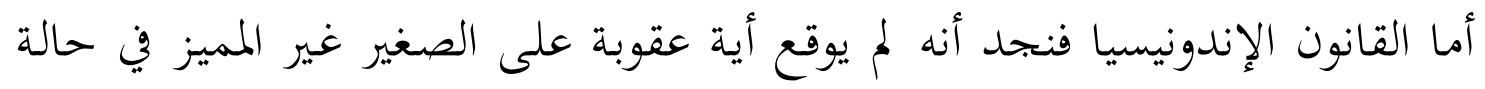

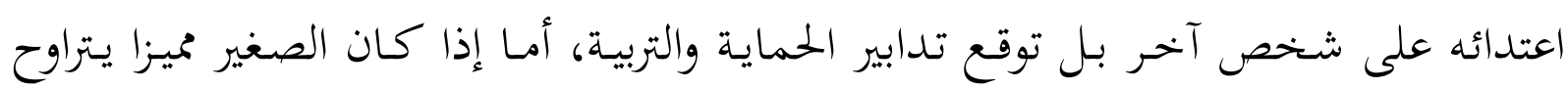

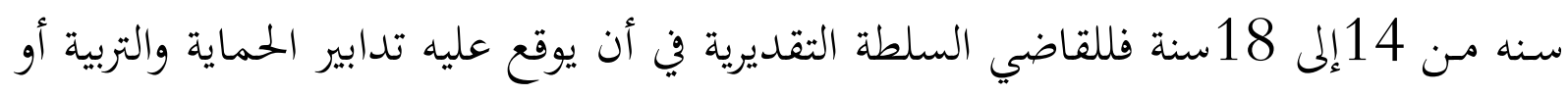
يسلط عليه عقوبة مخففة تساوي نصف عقوبة البالغ وهذا ما يخالف فيه الفقه الإسلامي.

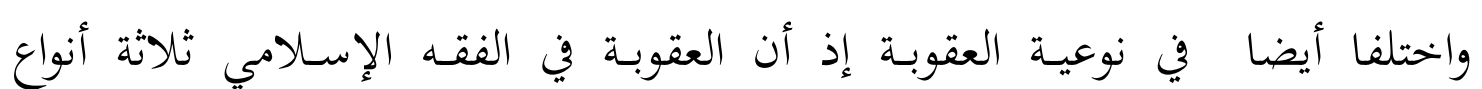

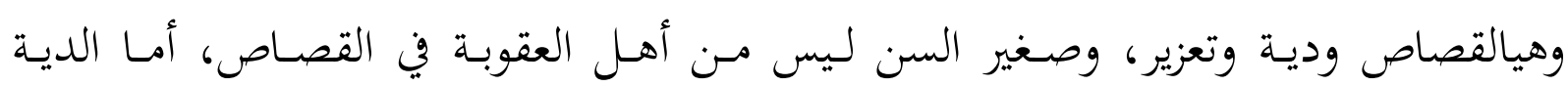

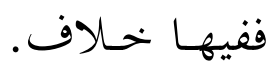


في حسين بهـد أننوعيـة العقوبـة في القـانون الإندونيسياهي عقوبة الإعدام والسـجن وعقوبة الجزاءات في حـال اختيـار القاضي للعقوبـة بدل دبير الحماية والتربية.

\section{المراجع}

$$
\begin{aligned}
& \text { ابو بكر محمد بن أحمد أبي سهل السرخسي. (1993). المبسوط، ـ بيروت: دار المعرفة. } \\
& \text { أبي بكر أحمد بن علي. (بلا تاريخ). أحكام القرآن. بيروت، لبنان: دار الكتاب العربي. } \\
& \text { ابن الهمام • (1987). شرح فتح القدير مع تكملته نتائج الأفكار مصر: المطابع الأميرية. } \\
& \text { ابن تيمية. (2005). مجموع الفتاوى. مصر: دار الوفاء للطباعة والنشر. } \\
& \text { ابن حزم. (بلا تاريخ). المحلى، تحقيق عبد الغغار سليمان البنداري. دار الكتب العلمية، بيروت. } \\
& \text { ابن قدامة. (1997) المغني. دار عالم الكتب. } \\
& \text { إبن منظور ( (بلا تاريخ). لسان العرب، دار صادر، بيروت. }
\end{aligned}
$$

أبو إسحاق الشاطبي. (بلا تاريخ). الاعتصام.دار الكتب الخديوية ، مطبعة المنار ، مصر أبو الحسين .(1979) .معجم مقايس اللغة .المحقق: عبد السلام محمد هارون، دار الفكر.

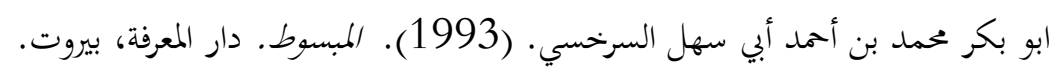$$
\text { أبو داود. (بلا تاريخ). سنن أبي داود، كتاب الصلاة، باب متى يؤمر الغلام بالصلاة. }
$$

أبي الحسن محمد اللكنوي. (بلا تاريخ). كتاب الفوائد البهيةفيتراجمالحنفية (صفحة 163). بيروت، لبنان: دار المعرفة للطباعة

$$
\text { والنشر. }
$$

أحمد الزرقاء(بلا تاريخ)المدخل الفقهي العام.بيروت :.دار الفكرن .

الخرشي. (بلا تاريخ). شرح على مختصر خليل،. بيروت: دار الفكر للطباعة.

$$
\text { الشوكاني. (1993). : : نيل الأوطار. مصر.: دار الحديث. }
$$

الكاساني. (1982). بلدائع الصنائع. بيروت، لبنان: دار الكتاب العربي .

النووي. (بلا تاريخ). كتاب المجموع، تحقيق محمل بجيب المطيعي. مكتبة الإرشاد جدة، المملكة العربية السعودية. 


$$
\begin{aligned}
& \text { النووي. (2003). روضة الطالبين. دار عالم الكتب. } \\
& \text { سعد الدين مسعود بن عمر لتفتازائ. (بلا تاريخ). شرح التلويح على التوضيح لمتن التنقيح، تحقيق زكريا عميرات . بيروت، لبنان: دار } \\
& \text { الكتب العلمية. } \\
& \text { سعدي أبو جيب. (بلا تاريخ). القاموس الفقهي لغة واصطلاحا. بيروت: دار الفكر. } \\
& \text { عبد العزيزبن سعود سعد الحارثي. (2012). سن المسئولية الجنائية للطفل في النظام السعودي. دراسة تأصيلية مقارنة بالمواثيق } \\
& \text { الدولية . } \\
& \text { عبد القادر عودة. (2003). التشريع الجنائي الإسلامي مقارنا بالقانون الوضعي. القاهرة: مكتبة دار التراث. } \\
& \text { عبد الوهاب عبدول. (بلا تاريخ). مصطفى أحمد الزرقاء، المسؤولية الجنائية للأحداث الملدخل الفقهي العام. } \\
& \text { محمد بن عابدين. (1979). حاشية رد الختار على الدر المختار شرح تنوير الأبصار. بيروت: دار الفكر. } \\
& \text { محمود سليمان موسى. (2006). قانون الطفولة الجانحة والمعاملة الجنائية للأحداث،. الإسكندرية، مصر: منشأة المعارف. } \\
& \text { محمود بحيد بن سعود كبيسي. (1986). الصغير بين أهلية الوجوب ؤهلية الأداء. المملكة العبية السعودية: رسالة ماجستير غير } \\
& \text { منشورة، جامعة أم القرى . } \\
& \text { منصور بن يونس بن ادريس البهوتي. (بلا تاريخ). كشاف القناع عن متن الاقناع. رياض: مكتب النصر الحديثة . } \\
& \text { موسى إبن سعيد. (2009). أثر صغر السن في المسئولية الجنائية في الفقه الإسلامي والقانون الجزائري رسالة دكتورة. الجزائر: جامعة } \\
& \text { الحاج لحضر. } \\
& \text { وهبة الزحيلي. (2000). الفقه الإسلامي ؤأدلنه. دمشق: دار الفكر. }
\end{aligned}
$$

Gultom, M. (2006). In Perlindungan Hukum Terhadap Anak. Bandung: Refika Aditama.

KPAI. (2018). bankdata.kpai.go.id. Retrieved from bank data kpai:

http://bankdata.kpai.go.id/tabulasi-data/data-kasus-per-tahun/rincian-data-kasus-

berdasarkan-klaster-perlindungan-anak-2011-2016

Risalah. (1996). In Risalah Rapat Kerja Pansus Rancangan Undang-Undang Peradilan Anak. 